\section{Growth Factors as Survival Factors: Regulation of Apoptosis}

Mary K. L. Collins, Gordon R. Perkins, Gemma Rodriguez-Tarduchy, María Angela Nieto and Abelardo López-Rivas

Accepted 14 October, 1993

\section{Summary}

Apoptosis is now widely recognized as a common form of cell death and represents a mechanism of cell clearance in many physiological situations where deletion of cells is required. Peptide growth factors, initially characterised as stimulators of cell proliferation, have now been shown to inhibit death in many cell types. Deprivation of growth factors leads to the induction of apoptosis, i.e. condensation of chromatin and degradation in oligonucleosomesized fragments, formation of plasma and nuclear membrane blebs and cell fragmentation into apoptotic bodies which can be taken up by neighbouring cells. Here we discuss the mechanism(s) by which growth factors may inhibit apoptosis.

\section{Apoptosis: an overview}

Often referred to as programmed cell death, apoptosis has been extensively reported in the scientific literature through morphological studies in many tissues where death was taking place as a consequence of a physiological phenomenon (reviewed in ref. 1). In these studies the presence of scattered single cells with highly condensed chromatin has been one of the parameters indicating the presence of apoptotic cell death $^{(2)}$. In a later phase the chromatin appears to be distributed into sub-cellular structures called apoptotic bodies ${ }^{(3)}$.

However, apoptosis is not only observed in the balanced situation of physiological tissue turnover but also in the elimination of specific cell subsets that occurs in embryogenesis, for instance in the embryonic development of the intestine and nervous system and in the regression of female sexual organs in the male ${ }^{(4)}$. Apoptosis has also been implicated as the mechanism of cell elimination during tissue regression in metamorphosis ${ }^{(5)}$. Apoptotic cells have also been observed during tumour growth and regression. Thus, for example, apoptotic bodies of epithelial cell origin were described during development of squamous cell carcinoma ${ }^{(6)}$ and kinetics studies have demonstrated waves of apoptosis during sarcoma growth ${ }^{(7)}$. Therefore, during tumour growth some cells, perhaps those deprived of growth factors, undergo apoptosis. When tumours are treated with chemotherapy, apoptosis is responsible for at least some of the cell deaths which ensue ${ }^{(8)}$.
There are further experimental modulations of tissues where cell death is induced and apoptosis is observed. Regression of hyperplastic organs such as the liver or kidneys after lead poisoning is accompanied by the appearance of apoptotic cells ${ }^{(9)}$. Apoptosis is observed in the rat prostate after repeated withdrawal of testosterone stimulation ${ }^{(10)}$, in rat liver after removal of tumour promoters ${ }^{(11)}$, in keratinocytes after UV irradiation ${ }^{(12)}$ and in neuronal cells following glutamate treatment ${ }^{(13)}$.

Because apoptotic cells are rapidly, and specifically, engulfed in vivo by neighbouring cells ${ }^{(14)}$ in order to keep cell debris to a minimum and to allow shrinkage of a tissue without disruption of its basic architecture, these morphological tissue studies probably greatly underestimate the number of deaths occurring. Indeed, it has been proposed that many cells in the normal animal are undergoing apoptosis, and that those which fail to enter this cell death program are rescued by essential 'survival factors'(15). This has been most conclusively demonstrated for glial cells of the rat optic nerve. If the peptide factor platelet-derived growth factor (PDGF) is supplied to the developing nerve, a decrease in the number of apoptotic oligodendrocyte progenitor cells and an increase in the final number of oligodendrocytes are observed ${ }^{(16)}$. More mature oligodendrocytes are dependent on the supply of ciliary neurotrophic factor (CNTF) from the neurons which they myelinate and apoptose in its absence ${ }^{(17)}$. Developing neuronal cells themselves die in the absence of nerve growth factor (NGF), produced by the target cells which they ennervate $^{(18)}$, and administration of exogenous NGF to prenatal rats decreases the death of sympathetic neurons ${ }^{(19)}$. Thus, one can imagine that many cells are kept alive by a complex network of paracrine survival factors, the levels of which control the balance of cell populations. The purpose of this review is to discuss the mechanism by which factor deprivation can lead to apoptosis and to describe situations in which peptide growth factors act as survival factors.

\section{Growth factor deprivation}

The mechanism by which growth factor removal can lead to apoptosis can best be studied in cells in culture. A wide variety of cells maintained in culture have been shown to undergo apoptosis when deprived of essential growth factors. These include vascular endothelial cells deprived of fibroblast growth factor (FGF) ${ }^{(20)}$, mouse embryo cells after epidermal growth factor (EGF) removal ${ }^{(21)}$, rat pheochromocytoma PC12 cell line and sympathetic neurons deprived of $\mathrm{NGF}^{(22)}$, hormone-dependent cells of the breast or prostate deprived of steroids ${ }^{(23,24)}$ and glial cells deprived of $\mathrm{PDGF}^{(16)}$. In the hemopoietic and immune systems there are numerous reports of the induction of a cell death program by apoptosis after withdrawal of specific growth factors. It was first described ${ }^{(25)}$ that interleukin-2 (IL2)-dependent T lymphocytes enter a program of endonuclease activation and cell death by apoptosis when IL-2 is removed from the culture medium. Germinal centre B lymphocytes also enter apoptosis in the absence of antigen receptor triggering ${ }^{(26)}$. A similar mechanism seems to operate to regulate the development of all cells of the hemopoietic system from multipotential pre- 


\section{Growth Factor Deprivation}

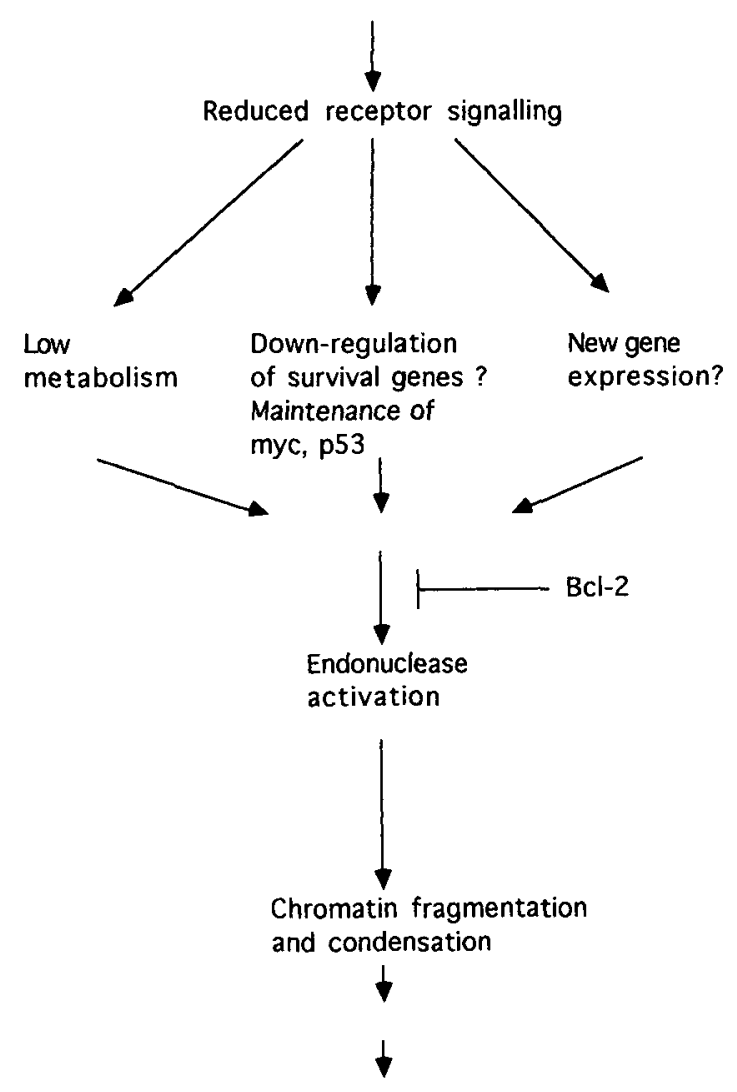

\section{Cell death}

Fig. 1. Signalling pathways leading to apoptosis during growth factor deprivation.

cursors in bone marrow. This has been demonstrated in several interleukin-3 (IL3)-dependent progenitor cell lines ${ }^{(27,28)}$, in activated erythroid progenitor cells after erythropoietin removal ${ }^{(29)}$ and in primary cultures of bone marrow after their removal from the marrow microenvironment ${ }^{(28)}$.

The mechanism by which growth factor removal may lead to apoptosis is represented in Fig. 1. The signal transduction pathways and patterns of gene expression maintained in the presence of diverse growth factors are clearly not identical. They will however all decline upon removal of factor, which will lead in many cases to a decrease in basic cell functions, such as metabolic rate ${ }^{(30)}$. A change in the pattern of gene expression in the cell will also occur. Recent experiments have demonstrated that an 'imbalance' in expression of genes involved in the stimulation of proliferation by growth factors may be responsible for entry into apoptosis upon factor removal. These studies demonstrate that constitutive expression of c-myc in fibroblasts results in cells which apoptose rather than arrest upon serum removal ${ }^{(31)}$. High levels of myc are also expressed by activated hemopoietic cells, and additional myc expression leads to more rapid apoptosis in IL3-dependent cells ${ }^{(32)}$.
Whether new gene expression is required for apoptosis following factor removal remains unclear. For example, protein synthesis inhibitors slow the rate of death in some hemopoietic cell lines deprived of IL $3^{(27)}$, but protein or RNA synthesis inhibitors do not affect entry into apoptosis in the murine IL3-dependent cell line BAF3, when IL3 is removed ${ }^{(28)}$.

Transformed cells may be those which either proliferate upon growth factor removal, or fail to undergo apoptosis in the absense of factor. The oncogene $b c l$ - 2 was first identified as being translocated to the immunoglobulin locus, and therefore over-expressed, in a class of B cell lymphomas ${ }^{(33)}$. Transgenic mice over-expressing the $b c l-2$ gene product in $\mathrm{T}$ or $\mathrm{B}$ lymphocytes show greatly reduced apoptosis of these cells ${ }^{(34,35)}$. Transfection and overexpression of the $b c l-2$ gene in hemopoietic cell lines inhibits apoptosis following IL3 removal(36), its introduction into neurons prevents apoptosis upon withdrawal of NGF(37), and it inhibits apoptosis when serum is removed from fibroblasts constitutively expressing c-myc ${ }^{(38)}$. The bcl-2 gene product is a $30 \mathrm{kDa}$ protein localised partly in mitochondria(36) and also associated with other cell membranes ${ }^{(50)}$. How the protein inhibits cell death is unknown, but its inhibits a variety of apoptotic pathways (see also below), suggesting that it may act at a late, common step. The down-regulation of expression of 'survival genes', including $b c l-2^{(36)}$, may be an event that follows growth factor removal; however we have demonstrated that loss of $b c l-2$ expression does not precede apoptosis when IL 3 is removed from BAF3 cells ${ }^{(40)}$. The tumour suppressor gene $p 53$ is probably involved in the stimulation of apoptosis when at least some growth factors are removed, as loss of wild-type p53 function allows factor-dependent cells to escape apoptosis on IL6 removal ${ }^{(41)}$.

The earliest step that is definitely common to many cells entering apoptosis following factor removal is the appearance of oligonucleosome-length fragments of chromatin. This is the result of digestion of the nuclear DNA by endogenous endonucleases, which cut in the linker region where the DNA is most accessible. In BAF3 cells deprived of IL3, it is clear that an event close to the start of DNA fragmentation is the first irreversible step, as IL3 re-addition can rescue cells at this time ${ }^{(42)}$. A nuclease stimulated by supraphysiological $(\mathrm{mM})$ levels of calcium has been identified in thymocyte nuclei $^{(43)}$, and there is some evidence that this enzyme may be related to the pancreatic digestive enzyme DNAse $\mathrm{I}^{(44)}$. However, IL3-dependent cells which apoptose do not express this activity ${ }^{(45)}$, suggesting the existence of some cell specificity in the nucleases involved in apoptosis. There is also conflicting data regarding the role of endonuclease activation in the onset of the apoptotic pathway. Experiments using millimolar levels of zinc, an inhibitor of the calciumstimulated nuclease, show either inhibition ${ }^{(43)}$ or no inhibition ${ }^{(46)}$ of cell death. Another nuclease inhibitor, aurintricarboxlic acid, can inhibit cell death, for example in neuronal cells deprived of $\mathrm{NGF}^{(22)}$. These inhibitors are rather nonspecific, which may explain the different results. 


\section{Growth Factor Addition}

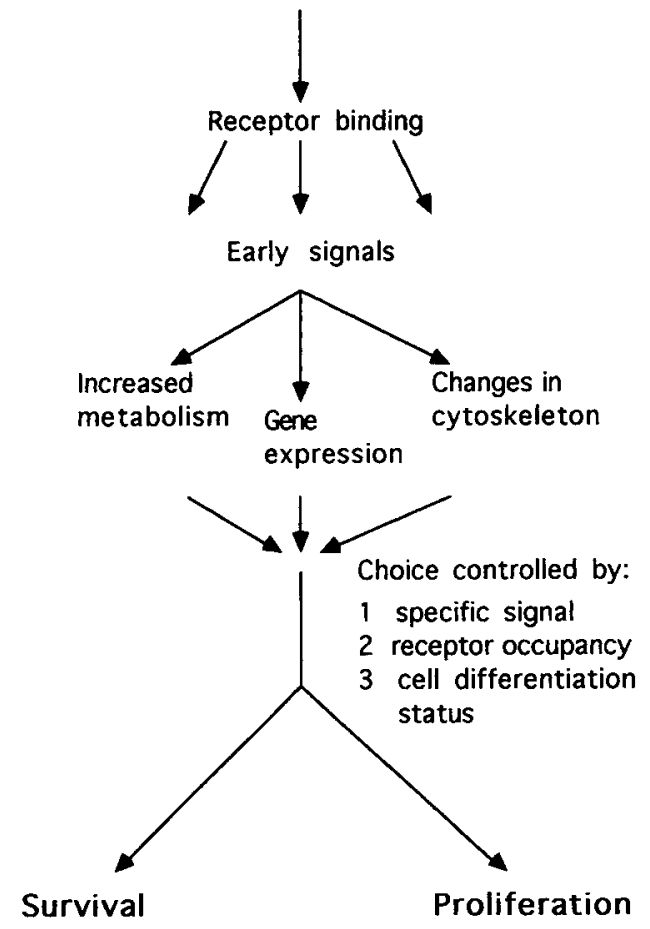

Fig. 2. Stimulation by growth factors of cell survival and proliferation.

\section{Growth factor addition - the choice between proliferation and survival}

An overview of the events that follow growth factor addition to cells is presented in Fig. 2 and reviewed in ${ }^{(47)}$. Unlike growth factor deprivation, it is clear that growth factor addition requires new gene expression and protein synthesis in order to stimulate cell proliferation. Consideration of the pathways by which peptide growth factors can stimulate cell proliferation is beyond the scope of this review; what will be summarised are the mechanisms that may control whether a growth factor stimulates proliferation, or promotes cell survival, in a given target cell. Firstly, it is possible that some factors may trigger specific signalling pathways which stimulate cell survival rather than cell proliferation. For example, insulin-like growth factor I (IGF-I) promotes survival, but not proliferation, of glial cells ${ }^{(16)}$. IGF-I also promotes survival of bone marrow-derived IL3-dependent cell lines and primary cultures, but stimulates much less rapid proliferation than IL $3^{(48)}$. In these cells interleukin 4 (IL4) also promotes survival but not rapid proliferation ${ }^{(45)}$. Thus the different rapid signals triggered by IGF-1 ${ }^{(49)}$ or IL $4^{(50)}$, compared to those stimulated by IL $3^{(50)}$, may favour survival rather than proliferation. IL3 itself stimulates survival but not maximal proliferation when added in the presence of rapamycin ${ }^{(51)}$ which inhibits $p 70$ S6 kinase activation, suggesting that some of the multiple signalling pathways stimulated by IL3 promote survival rather than proliferation. Furthermore, analysis of receptor isoforms suggested that different regions of the cytoplasmic domain of the erythropoietin receptor are coupled to proliferation and survival pathways ${ }^{(52)}$.

The level of growth factor receptor occupancy can also control the decision of a cell to survive or proliferate in the presence of a given growth factor. Fig. 3 shows that the choice between survival and proliferation by an IL3-dependent cell line, BAF3, can be regulated by the level of IL3 supplied. Low concentrations of IL3 can maintain cell viability, while failing to stimulate cell proliferation. To demonstrate that this choice was controlled by the level of receptor occupancy, the behaviour of 3 cell transfectants expressing intermediate (B8), low (B18), or very low (B3) levels of the interleukin 2 (IL2) receptor $\beta$ chain was examined. Parental BAF3 cells fail to survive or proliferate in IL2, while transfectants expressing high levels of IL 2 receptor $\beta$ chain $(600$ intermediate affinity receptors/cell) survive and proliferate as well in IL2 as in IL $3^{(53)}$. High concentrations of IL2 can maintain survival, but stimulate very little proliferation in cells expressing sub-optimal levels of receptor (Fig. 3). These data imply that the choice between cell survival and proliferation may be regulated both by the level of factor available and by the level of receptor expressed.

Some differentiated cells are unable to divide, but still require survival factors to inhibit apoptosis. These include neuronal cells which require $\mathrm{NGF}^{(18)}$ and eosinophils which die in the absence of interleukin 5 (IL5) ${ }^{(54)}$. Immortal cells in culture, such as fibroblasts, can arrest and survive in the absence of growth factors. However, whether all non-transformed cells, if they are able to arrest their division, still require survival factors for their maintenance remains an open question.

\section{Positive signalling of apoptosis}

Glucocorticoids are potent immunosuppressive hormones produced by the adrenal cortex in response to adrenalin; they therefore provide a link between the nervous and immune systems. It was first demonstrated by Wyllie ${ }^{(55)}$ that treatment of lymphoid cells with glucocorticoids induced a cell death programme involving the fragmentation of cell chromatin into oligonucleosomes by an endogenous endonuclease (Fig. 4). This induction of apoptosis requires the regions of the glucocorticoid receptor that are known to be required for transactivation of gene expression ${ }^{(56)}$ and is blocked by inhibition of protein synthesis, implying that de novo gene expression is required. This induction of apoptosis probably explains the efficacy of glucocorticoids in the treatment of leukaemia ${ }^{(57) .}$ Many other cancer therapy regimes, including DNA damaging drugs (see for example ref. 8) and inhibitors of nucleotide metabolism ${ }^{(58)}$, also induce apoptosis in the target tumour cells. Like glucocorticoids, DNA damaging agents also require protein synthesis to stimulate apoptosis $^{(42)}$. The stimulation of apoptosis in T lymphocytes by glucocorticoids can be inhibited by the growth factor IL2 ${ }^{(59)}$, or by over-expression of $b c l-2^{(34)}$. Likewise the stimulation of apoptosis by DNA damaging agents can be blocked by $b c l-2$ over-expression in a variety of cells ${ }^{(34,38,42)}$ and by IL3 in bone marrow cells ${ }^{(42)}$. p53 is probably involved in the induc- 


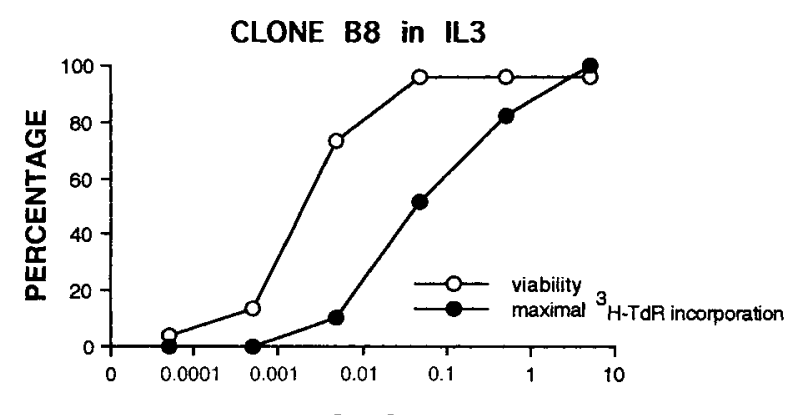

[IL 3] $(\% \mathrm{CM})$

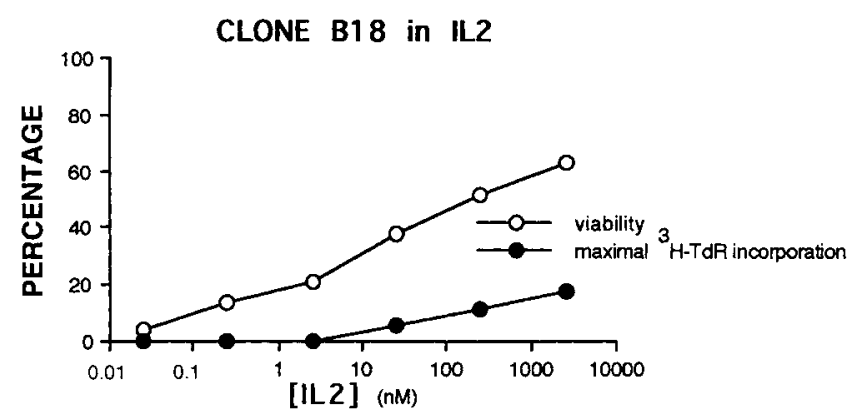

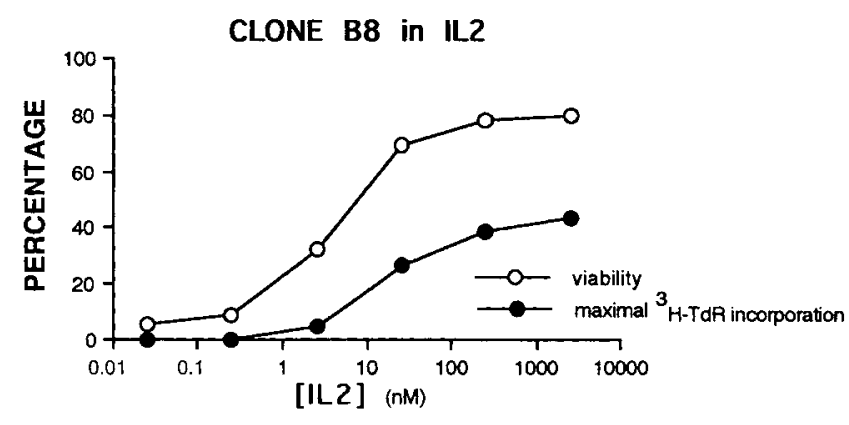

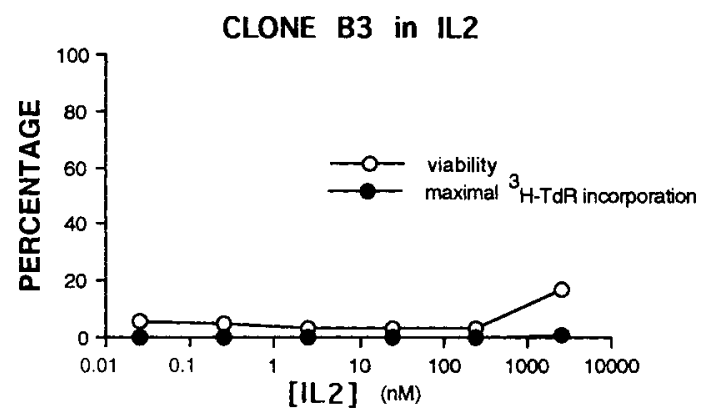

Fig. 3. Receptor occupancy controls the choice between survival and proliferation. Clones of BAF3 cells expressing various levels of IL2 receptor $\beta$ chain were prepared as previously described ${ }^{(53)}$ using a recombinant retrovirus encoding human IL2 receptor $\beta$ chain. Clone B8 expresses 82 intermediate affinity IL2 receptors/cell, clone B 18 expresses 11 receptors/cell and clone B3<5 receptors/cell. The three clones respond identically to parental BAF3 cells in IL3; the response of clone B8 to IL3-containing conditioned medium (CM) ${ }^{(51)}$ is shown. The response of the three clones to recombinant human IL2, at the concentration shown, is depicted.

tion of apoptosis following DNA damage, as p53 protein is induced upon exposure of cells to DNA damaging agents and mice homozygously deleted for the $\mathrm{p} 53$ gene are less sensitive to DNA damage-induced apoptosis ${ }^{(60)}$.

Positive triggering of apoptosis has also been extensively studied in the thymus, where immature $T$ cells which recognise self antigens, and are therefore harmful, are eliminated. Apoptosis can be stimulated in thymocytes by addition of antibodies which cross-link antigen receptors, or by addition of antigen to thymocytes in organ culture or in vivo ${ }^{(61,62)}$. It is blocked by inhibition of protein synthesis ${ }^{(43)}$, by $b c l$-2 overexpression $^{(34)}$ and by the growth factors IL1 ${ }^{(63)}$ and IL $2^{(64)}$. Apoptosis in thymocytes is also inhibited by stimulation of protein kinase $\mathrm{C}$, but stimulated by agents which elevate cyclic AMP or calcium. Why thymocyte antigen receptor triggering leads to apoptosis, whereas mature $T$ cell antigen receptor triggering leads to proliferation, remains unclear. The fact that such cells can be rescued by growth factors suggests that they are analogous to the 'partially activated' fibroblasts which constitutively express c-myc, and that insufficient growth factors are produced when cells are stimulated in the thymic micro-environment or in culture to rescue activated cells (Fig. 4). Indeed inhibition of c-myc expression can prevent apoptosis induced by antigen receptor triggering in a $\mathrm{T}$ cell hybridoma ${ }^{(65)}$. Mature $\mathrm{T}$ lymphocytes can also be induced to apoptose if triggering of the auxilliary surface molecule $\mathrm{CD} 4$ is uncoupled from triggering of the antigen receptor. This may explain some of the cell death by apoptosis seen in lymphocytes of human immunodeficiency virus type 1 (HIV-1)-infected individuals, as the HIV1 envelope can trigger apoptosis by binding to $\mathrm{CD} 4^{(66)}$.

Finally, there is at least one mechanism of apoptosis induction which is not known to be inhibited by growth factors or by $b c l-2$ overexpression (see Fig. 4). Cytotoxic T lymphocytes induce apoptosis in their target cells (reviewed in ref. 67). A nuclease in the target cell is responsible for chromatin fragmentation, though this is not essential for cell

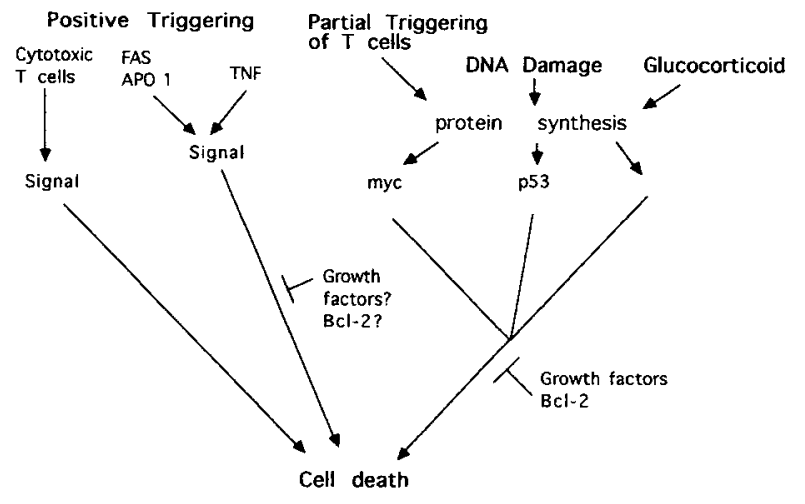

Fig. 4. Positive signalling of apoptosis. 
death ${ }^{(68)}$. This process is not inhibited by $b c l-2$ overexpression ${ }^{(69)}$.

Triggering of the murine cell surface antigen Fas and its human homologue APO-1 also induces apoptosis. Mice defective in Fas are unable to remove self-reactive thymocytes by apoptosis and therefore suffer from auto-immune disorders ${ }^{(70)}$. Fas has also been implicated in the induction of apoptosis by cytotoxic $\mathrm{T}$ lymphocytes ${ }^{(71)}$. Antibodies to APO- 1 induce apoptosis in some cells ${ }^{(72)}$, but can also stimulate proliferation in others. This may imply that Fas/APO-1 can act a little like the $\mathrm{T}$ cell antigen receptor and stimulate either proliferation or apoptosis. Likewise, tumour necrosis factor- $\alpha$ (TNF- $\alpha$ ) can stimulate either apoptosis (reviewed in ref. 67) or proliferation ${ }^{(73)}$ of target cells. The cellular receptor for TNF- $\alpha$ is homologous to Fas/APO-1 and it may therefore be possible that they generate similar second messengers which lead to apoptosis in some cells. Indeed, addition of ceramide, a sphingolipid precursor generated by TNF- $\alpha$ receptor triggering, can induce apoptosis in lymphoid cells $^{(74)}$. Although it is not completely clear, induction of apoptosis by TNF- $\alpha$ or anti-APO- 1 may also be inhibited by growth factors or $\mathrm{Bcl}-2$, since it has been shown that TNF- $\alpha$ induced apoptosis can be inhibited by the survival factor CNTF in glial cells ${ }^{(75)}$ and APO-1-induced apoptosis may be inhibited by $b c l-2$ expression. This raises the interesting possibility that growth factors may also play an inhibitory role in almost all situations in which apoptosis is positively stimulated, and suggests that regulation of growth factor levels is not only of paramount importance in the control of cell proliferation but also in maintaining viability of cells susceptible to undergoing apoptosis.

\section{Acknowledgement}

This work was supported by the Comisión Interministerial de Ciencia y Tecnología (SAL91-0411) and the Cancer Research Campaign.

\section{References}

1 Wyllie, A.H., Kerr, J.F.R. and Currie, A.R. (1980). Cell death: the significance of apoptosis. Int. Rev. Cytol. 68, 251-270.

2 Duvall, E. and Wyllie, A.H. (1986). Death and the cell. Immunol. Today 7, 115-119. 3 Wyllie, A.H. and Morris, R.G. (1982). Hormone-induced cell death. Purification and properties of thymocytes undergoing apoptosis after glucocorticoid treatment. Am. J. Pathol. 109, 78-85.

4 Hinchliffe, J.R. (1981). Cell death in embryogenesis. In Cell Death and Biology and Pathology, (ed. R.A. Lockshin and I.D. Bowen), pp. 35-78. New York: Chapman and Hall.

5 Ellis, L.C. and Youson, J.H. (1990). Pronephric regression during larval life in the sea lamprey, Petromyzon marinus. A histochemical and ultrastructural study. Anat. Embryol. Berl. 182, 41-52.

6 el-Labban, N.G. and Osorio-Herrera, E. (1986). Apoptotic bodies and abnormally dividing epithelial cells in squamous cell carcinoma. Histopathology 10, 921-931.

7 Sarraf, C.E. and Bowen, I.D. (1986). Kinetic studies on a murine sarcoma and an analysis of apoptosis. Br. J. Cancer. 54, 989-998.

8 Sorenson, C., Barry, M. and Eastman, A. (1990). Analysis of events associated with cell cycle arrest at G2 and cell death induced by cisplatin. J. Natl. Cancer Inst. 82, 749-756.

9 Columbano, A., Ledda-Columbano, G.M., Coni, P.P., Fee, G., Liguori, C., Santa-Cruz, G. and Pani, P. (1985). Occurrence of cell death (apoptosis) during involution of liver hyperplasia. Lab. Invest. 52, 670-675.

10 Sandford, N.L., Searle, J.W. and Kerr, J.F. (1984). Successive waves of apoptosis in the rat prostate after repeated withdrawal of testosterone stimulation. Pathology 16, 406-410.

11 Bursch, W., Lauer, B., Timmermann, I., Barthel, G., Schuppler, J. and Schulte-
Hermann, R. (1984). Controlled death (apoptosis) of normal and putative preneoplastic cells in rat liver following withdrawal of tumor promoters. Carcinogenesis 5, 453-458.

12 Young, A.R. (1987). The sunburn cell. Photodermatol. 4, 127-134.

13 Kure, S., Tominaga, T., Yoshimoto, T., Tada, K. and Narisawa, K. (1991). Glutamate triggers internucleosomal DNA cleavage in neuronal cells. Biochem. biophys. Res. Commun. 179, 39-45.

14 Savill, J., Fadok, V., Henson, P. and Haslett, C. (1993). Phagocytic recognition of cells undergoing apoptosis. Immunol. Today 14, 131-136.

15 Raff, M.C. (1992). Social control on cell survival and cell death. Nature 356, 397 400.

16 Barres, B.A., Hart, I.K., Coles, S.R., Burne, J.F., Voyvodic, J.T., Richardson, W.D. and Raff, M.C. (1992). Cell death and control of cell survival in the oligodendrocyte lineage. Cell 70, 31-46.

17 Barres, B.A., Schmid, R., Sendnter, M. and Raff, M.C. (1993). Multiple extracellular signals are required for long-term oligodendrocyte survival. Development (in press)

18 Mesner, P.W., Winters, T.R. and Green, S.H. (1992). Nerve growth factor withdrawal-induced cell death in neuronal PC12 cells resembles that in sympathetic neurons. J. Cell Biol. 119, 1669-1680.

19 Levi-Montalcini, R. (1987). The nerve growth factor: thirty-five years later. EMBO J. 6, 1145-1154.

20 Araki, S., Shimada, Y., Kaji, K. and Hayashi, H. (1990). Apoptosis of vascular endothelial cells by fibroblast growth factor deprivation. Biochem. Biophys. Res. Commun. 168, 1194-1200.

21 Rawson, C.L., Loo, D.T., Duimstra, J.R., Hedstrom, O.R., Schmidt, E.E. and Barnes, D.W. (1991). Death of serum-free mouse embryo cells caused by epidermal growth factor deprivation. J. Cell. Biol. 113, 671-680.

22 Batistatou, A. and Greene, L.A. (1991). Aurintricarboxylic acid rescues PC12 cells and sympathetic neurons from cell death caused by nerve growth factor deprivation: Correlation with suppression of endonuclease activity. J. Cell. Biol. 115, $461-471$.

23 Bardon, S., Vignon, F., Montcourrier, P. and Rochefort, H. (1987). Steroid receptor-mediated cytotoxicity of an antioestrogen and an antiprogestin in breast cancer cells. Cancer Res. 47, 1441-1448.

24 Kerr, J.F.R. and Searle, J. (1973). Deletion of cells by apoptosis during castrationinduced involution of the rat prostate. Virchows arch. B 13, 87-92.

25 Duke, R.C. and Cohen, J.J. (1986). IL-2 addiction: withdrawal of growth factor activates a suicide program in dependent T cells. Lymphokine Res, 5, 289-295.

26 Liu, Y.J., Joshua, D.E., Williams, G.T., Smith, C.A., Gordon, J. and MacLennan, I.C. (1989). Mechanism of antigen-driven selection in germinal centres. Nature 342, 929-931.

27 Williams, G.T., Smith, C.A., Spooncer, E., Dexter, T.M. and Taylor, D.R. (1990). Haemopoietic colony stimulating factors promote cell survival by suppressing apoptosis. Nature 343, 76-79.

28 Rodriguez-Tarduchy, G., Collins, M. and López-Rivas, A. (1990). Regulation of apoptosis in interleukin-3-dependent hemopoietic cells by interleukin-3 and calcium ionophores. EMBO 9, 2997-3002

29 Koury, M.J. and Bondurant, M.C. (1990). Erythropoietin retards DNA breakdown and prevents apoptosis in erythroid progenitor cells. Science 248, 378-381. 30 Whetton, A.D. and Dexter, T.M. (1983). Effect of haemopoietic cell growth factor on intracellular ATP levels. Nature 303, 629-632.

31 Evan, G.I., Wyllie, A.H., Gilbert, C.S., Littlewood, T.D., Land, H., Brooks, M., Waters, C.M., Penn, L.Z. and Hancock, D.C. (1992). Induction of apoptosis in fibroblasts by c-myc protein. Cell 69, 119-128.

32 Askew, D.S., Ashmun, R.A., Simmons, B.C. and Cleveland, J.L. (1991). Constitutive c-myc expression in an IL3-dependent myeloid cell line suppresses cell cycle arrest and accelerates apoptosis. Oncogene 6, 1915-1922.

33 Cleary, M.L., Smith, S.D. and Sklar, J. (1986). Cloning and structural analysis of cDNAs for $b c l-2$ and a hybrid $b c l-2 /$ immunoglobulin transcript resulting from the t(14:18) translocation. Cell 47, 19-28.

34 Strasser, A., Harris, A. and Cory, S. (1991). bct-2 transgene inhibits T cell death and peturbs thymic self-censorship. Cell 67, 889-894.

35 McDonnell, T.J., Deane, N., Platt, F.M., Nunez,G., Jaeger, U., McKearn, J.P. and Korsmeyer, S.J. (1989). bcl-2-immunoglobulin transgenic mice demonstrate extended B cell survival and follicular lymphoproliferation. Cell 57, 79-88.

36 Hockenberry, D., Nunez, G., Milliman, C., Schreber, R.D. and Korsmeyer, S.J. (1990). $\mathrm{Bcl}-2$ is an inner mitochondrial membrane protein that blocks programmed cell death. Nature 348, 334-336.

37 Garcia, I., Martinou, I., Tsujimoto, Y. and Martinou, J-C. (1992). Prevention of programmed cell death of sympathetic neurons by the $b c t-2$ prot-oncogene. Science 258, 302-304.

38 Fanidi, A., Harrington, E.A. and Evan, G.I. (1992). Cooperative interaction between c-myc and $b c l-2$ proto-oncogenes. Nature 359, 554-556.

39 Jacobson, M., Burne, J., King, M., Miyashita, T., Reed, J. and Raff, M.C. (1993). bcl-2 blocks apoptosis in cells lacking mitochondrial DNA. Nature 361, 365369

40 Marvel, J., Perkins, G.R., Lopez-Rivas, A. and Collins, M.K.L. (1994). bcl-2 over-expression can inhibit the stimulation of cell proliferation by IL3. Oncogene (in press). 
41 Yonish-Rouach, E., Resnitsky, D., Lotem, J., Sachs, L., Kimchi, A. and Oren, M. (1991). Wild-type p53 induces apoptosis of myeloid leukaemia cells that is inhibited by IL6. Nature 352, 345-347.

42 Collins, M.K.L., Marvel, J., Malde, P. and Lopez-Rivas, A. (1992). IL3 protects murine bone marrow cells from apoptosis induced by DNA damaging agents. $J$. Exp. Med. 176, 1043-1051.

43 Cohen, J.J. and Duke, R.C. (1984). Glucocorticoid activation of a calciumdependent endonuclease in thymocyte nuclei leads to cell death. $J$. Immunol. 132, 38 45 .

44 Peitsch, M., Polzar, B., Stephan, H., Crompton, T., MacDonald, H., Mannherz, H. and Tschopp, J. (1993). Characterisation of the endogenous deoxyribonuclease involved in DNA degradation during apoptosis (programmed cell death). EMBO J. 12 371-377.

45 Rodriguez-Tarduchy, G., Malde, P., Lopez-Rivas, A. and Collins, M.K.L. (1992). Inhibition of apoptosis by calcium ionophores in IL3-dependent bone marrow cells is dependent upon production of IL4. J. Immunol. 148, 1416-1424.

46 Cohen, G.M., Sun, X.M., Snowden, R.T., Dinsdale, D. and Skilleter, D.N. (1992). Key morphological features of apoptosis may occur in the absence of internucleosomal DNA fragmentation. Biochem. J. 286, 331-334.

47 Pardee, A.B. (1989). G1 events and regulation of cell proliferation. Science 246, 603-608.

48 Rodriguez-Tarduchy, G., Collins, M.K.L., Garcia, I. and Lopez-Rivas, A. (1992). Insulin-like growth factor-I inhibits apoptosis in mouse hemopoietic cells. $J$. Immunol. 149, 535-540.

49 Czech, M.P. (1989). Signal transmission by the insulin-like growth factors. Cell 59, 235.

50 Wang, L.-M., Keegan, A.D., Paul, W.E., Heidaran, M.A., Gutkind, J.S. and Pierce, J.H. (1992). IL4 activates a distinct signal transduction cascade from IL3 in factor-dependent myeloid cells. EMBO J. 11, 4899-4908

51 Perkins, G.R., Marvel, J. and Collins, M.K.L. (1993). Interleukin 2 activates extracellular signal-regulated protein kinase 2. J. Exp. Med. 178, 1429-1434.

52 Nakamura, Y., Komatsu, N. and Nakauchi, H. (1992). A truncated erythropoietin receptor fails to prevent programmed cell death in erythroid cells. Science $\mathbf{2 5 9}, 1138$ 1141.

53 Perkins, G.R., Flemming, C.L., Kabat, D. and Collins, M.K.L. (1993). The role of IL2 interaction with $\mathrm{p} 75$ and p55 receptor molecules in the stimulation of cell proliferation. Int. Immunol. (in press).

54 Stern, M., Meagher, L., Savill, J. and Haslett, C. (1992). Programmed cell death in the eosinophil leads to phagocytosis by macrophages and is modulated by IL5. $J$. Immunol. 148, 3543-3549.

55 Wyllie, A.H. (1980). Glucocorticoid induced thymocytes apoptosis is associated with endogenous endonuclease activation. Nature 284, 555-557.

56 Dieken, E.S. and Miesfield, R.L. (1992). Transcriptional transactivation functions localised to the glucocorticoid receptor $\mathrm{N}$ terminus are necessary for steroid induction of lymphocyte apoptosis. Mol. Cell. Biol. 12, 589-597.

57 Jacobs, A.D. and Gale, R.P. (1984). Recent advances in the biology and treatment of acute lymphoblastic leukaemia in adults. N. Engl. J. Med. 311, 1219-1231.

58 Carson, D.A., Wasson, D.B., Esparza, L.M., Carrera, C.J., Kipps, T.J. and Cottam, H.B. (1992). Oral antilymphocyte activity and induction of apoptosis by 2 chloro-2'-arabino-fluro-2'-deoxyadenosine. Proc. Natl. Acad. Sci. USA 89, $2970-2974$. 59 Nieto, M.A. and López-Rivas, A. (1989). IL2 protects T lymphocytes from glucocorticoid-induced DNA fragmentation and cell death. J. Immunol. 143, 41664170.

60 Kastan, M.B., Onyekwere, O., Sidrnsky, D., Vogelstein, B. and Craig, R.W. (1991). Participation of p53 protein in the cellular response to DNA damage. Cancer Res. 51, 6304-6311.
61 Smith, C.A., Williams, G.T., Kingston, R., Jenkinston E.J. and Owen, J.T. (1989). Antibodies to CD3/T-cell receptor complex induce death by apoptosis in inmature $\mathrm{T}$ cells in thymic cultures. Nature 337, 181-184.

62 Murphy, K.M., Heimberger, A.B. and Loh, D.Y. (1990). Induction by antigen of intrathymic apoptosis of CD4+CD8+TCRlo thymocytes in vivo. Science 250,1720 1723.

63 McConkey, D.J., Hartzell, P., Chow, S.C., Orrenius, S. and Jondal, M. (1990). Interleukin-1 inhibits $\mathrm{T}$ cell receptor-mediated apoptosis in immature thymocytes. $J$. Biol. Chem. 265, 3009-3011.

64 Nieto, M.A., Gonzalez, A., López-Rivas, A., Diaz-Espada, F. and Gambon, F. (1990). IL-2 protects against anti-CD3-induced cell death in human medullary thymocytes. J. Immunol. 145, 1364-1368.

65 Shi, Y., Glynn, J.M., Guilbert, L.J., Cotter, T.G., Bissonnette, R.P. and Green, D.R. (1992). Role for c-myc in activation-induced aopoptotic cell death in T cell hybridomas. Science 257, 212-214.

66 Banda, N.K., Bernier, J., Kurahara, D.K., Kurrle, R., Haigwood, N., Sekaly, RP. and Finkel, T.H. (1992). Crosslinking CD4 by human immunodeficiency virus gp 120 primes T cells for activation-induced apoptosis. J. Exp. Med. 176, 1099-1106. 67 Golstein, P., Ojcius, D. and Young, D.E. (1991) Cell death in the immune system. Immunol. Rev. 121, 29-65.

68 Ucker, D., Obermiller, P., Eckhart, W., Apgar, J., Berger, N. and Meyers, J. (1992). Genome digestion is a dispensable consequence of physiological cell death mediated by cytotoxic lymphocytes. Mol. Cell. Biol. 12,3060-3069.

69 Vaux, D., Aguila, H. and Weissman, I. (1992). bcl-2 prevents death of factordeprived cells but fails to prevent apoptosis in targets of cell mediated killing. Int. Immunol. 4, 821-824.

70 Watanabe-Fukunaga, R., Brannan, C.I., Copeland, N.G., Jenkins, N.A. and Nagata, S. (1992). Lymphoproliferation disorder in mice explained by defects in Fas antigen that mediates apoptosis. Nature 356, 314-317.

71 Rouvier, E., Luciani, M-F. and Golstein, P. (1993) Fas involvement in $\mathrm{Ca}^{++}$ independent T cell-mediated cytotoxicity. J. Exp. Med. 177, 195-200.

72 Trauth, B.C., Klas, C., Peters, A.M.J., Matzku, S., Moller, P., Falk, W., Debatin, K.M. and Krammer, P.H. (1989). Monoclonal antibody-mediated tumor regression by induction of apoptosis. Science 245, 301-304.

73 Hurme, M. (1988). Both ILI and TNF enhance thymocyte proliferation. Eur. $J$. Immunol. 18, 1303-1306.

74 Obeid, L.M., Linardic, C.M., Karolak, L.A. and Hannun, Y.A. (1993). Programmed cell death induced by ceramide. Science 259, 1769-1771.

75 Louis, J.-C., Magal, E., Takeyama, S. and Varon, S. (1993). CNTF protection of oligodendrocytes against natural and TNF-induced death. Science 259, 689-692.

Mary K. L. Collins and Gordon R. Perkins are at the Chester Beatty Laboratories, Institute of Cancer Research, Fulham, London, UK, Gemma Rodriguez-Tarduchy is at the Instituto de Investigaciones Biomédicas CSIC, Madrid, Spain, and María Angela Nieto is at the Instituto Cajal CSIC, Madrid, Spain. Abelardo López-Rivas* is at the Instituto de Parasitología y Biomedicina CSIC, c/ Ventanilla 11, 18001 Granada, Spain. *Author for correspondence. 